5 Research Square
Preprints are preliminary reports that have not undergone peer review.

They should not be considered conclusive, used to inform clinical practice, or referenced by the media as validated information.

\title{
Serpentinization as a route to liberating phosphorus on habitable worlds
}

\section{Matthew Pasek ( $\nabla$ mpasek@usf.edu )}

School of Geosciences, University of South Florida https://orcid.org/0000-0003-1280-9555

\section{Arthur Omran}

School of Geosciences, University of South Florida

\section{Carolyn Lang}

School of Geosciences, University of South Florida

\section{Maheen Gull}

School of Geosciences, University of South Florida

\section{Josh Abbatiello}

School of Geosciences, University of South Florida

\section{Tian Feng}

School of Geosciences, University of South Florida

\section{Lyle Garong}

School of Geosciences, University of South Florida

\section{Heather Abbott-Lyon}

Department of Chemistry, Kennesaw State University

\section{Article}

Keywords: Habitability, Serpentinization, Redox, Phosphorus

Posted Date: July 9th, 2020

DOI: https://doi.org/10.21203/rs.3.rs-37651/v1

License: (c) (1) This work is licensed under a Creative Commons Attribution 4.0 International License.

Read Full License 


\section{Abstract}

Planetary habitability is in part governed by nutrient availability, including the availability of the element phosphorus. The nutrient phosphorus plays roles in various necessary biochemical functions, and its biogeochemical cycling has been proposed to be extremely slow due to a strong coupling to the rock cycle via mineral weathering. Here we show a route to $\mathrm{P}$ liberation from water-rock reactions that are thought to be common throughout the Solar System. We report the speciation of phosphorus in serpentinite rocks to include the ion phosphite (HPO32- with P3+) and show that reduction of phosphate to phosphite is predicted from thermodynamic models of serpentinization. As a result, as olivine in ultramafic rocks alters to serpentine minerals, phosphorus as soluble phosphite should be released under low redox conditions, liberating this key nutrient for life. Thus, this element may be accessible to developing life where water is in direct contact with ultramafic rock, providing a source of this nutrient to potentially habitable worlds.

\section{Introduction}

Nutrients such as nitrogen $(\mathrm{N})$ and phosphorus $(\mathrm{P})$ limit ecosystem size in the absence of the evolutionary means to extract and/or fixate these elements. More specifically, the evolution of $\mathrm{N}$ fixation has generally resulted in $\mathrm{P}$ serving as the limiting nutrient in biomass [1]. Beyond the earth, planetary habitability is governed in part by nutrient availability, in addition to physical (pressure and temperature) and environmental (disequilibria) constraints. Phosphorus plays a critical role in biochemical functions [2-4], ranging from nucleic acids to metabolism, and as such, $P$ is actively scavenged and recycled by ecosystems $[1,5]$, and presumably is important elsewhere for the development of life, though there may be routes to life without phosphorus [6, 7].

Phosphorus is unique amongst the major biogenic elements in that its elemental cycle excludes a significant volatile phase (although volatile phosphine is present as a minor constituent, as reported by [8, 9]). All phosphorus ultimately originates from rocks and minerals. Within felsic rocks rich in $\mathrm{SiO}_{2}$, most phosphate is associated with calcium phosphate minerals such as apatite $\left(\mathrm{Ca}_{5}\left(\mathrm{PO}_{4}\right)_{3}(\mathrm{OH}, \mathrm{F}, \mathrm{Cl})\right)$ or rare earth element (REE) phosphates such as monazite (REE) $\mathrm{PO}_{4}$. Within ultramafic, $\mathrm{SiO}_{2}$-poor rocks $\mathrm{P}$ instead is generally associated with olivine dissolving at up to $100 \mathrm{ppm}$ within the crystal lattice, likely exchanging for $\mathrm{Si}$ in $\mathrm{SiO}_{4}$ tetrahedra [10-15].

This dichotomy of P-bearing minerals in vastly different silicate rocks raises an important question for planetary habitability, including that of the early earth: which mineral source of phosphorus is more important in a given environment? For instance, the felsic rocks generally have more $P$, and this $P$ is associated with apatite, which may dissolve via reactions with carbonate [16] or $\mathrm{NH}_{4}{ }^{+}$and sulfate $[17,18]$ prior to biological extraction. In contrast, if ultramafic rocks are more abundant (as suggested by the dominance of olivine in the upper mantle $[19,20])$, then the issue of a lower $P$ abundance in olivine is overcome by the sheer volume of this mineral. In both scenarios, the liberation of phosphorus requires 
water interacting with rock; in the case of felsic rocks this is through dissolution or ionic exchange with phosphate minerals, and in ultramafic rocks could occur through weathering and alteration of the rock.

The mode of availability of phosphorus as a nutrient would thus be dependent on the types of rock interacting with water in an environment. In the case of the early earth, ultramafic rocks are believed to have been more common due to the higher heat flux of upper mantle, which results in less differentiation and more ultramafic volcanism [21], the expression of which are the Archean komatiites [22]. Despite this likely dominance by ultramafic rocks, the Archean and Hadean both likely had some amount of more felsic rocks that comprised the early continents [23]. Beyond the earth the presumed habitable worlds include Mars, which bears a moderately $\mathrm{SiO}_{2}$-rich crust with phosphate availability likely constrained by dissolution [24]. Phosphorus on the potentially habitable moons Europa and Enceladus is instead likely constrained by reactions of the subsurface oceans with ultramafic rock formed during accretion and differentiation [24-26]. Most $P$ nutrient availability studies focus on felsic rock interactions such as dissolution [16-18, 24], and here we have chosen to investigate the potential for $P$ liberation from more ultramafic sources, given their volumetric abundance for both the early earth and for icy ocean moons.

In addition to these intrinsic sources of phosphorus, extrinsic sources such as meteorites may have delivered $P$ to the early earth, primarily as metal phosphides [28-33]. The advantage of such a source is that the reaction of water with phosphides liberates $\mathrm{P}$ as the ion phosphite $\left(\mathrm{HPO}_{3}{ }^{2-}\right)$ in which the oxidation state of $\mathrm{P}$ is +3 as opposed to +5 . Phosphite salts are generally much more soluble than the comparable phosphate salts [34], and hence the presence of phosphite may be a plausible free source of $P$ on a habitable world. However, such a source is less plausible for icy moons given the general difficulty of surface to ocean material transfer, as well as the fact that phosphides tend to be high-temperature, inner solar system phases [35].

Phosphite could be a P nutrient that would be more relevant to planetary habitability due to its higher solubility if there exist intrinsic sources. However, a dominant paradigm of phosphorus geochemistry is that phosphorus is synonymous with phosphate. This assumption is generally driven by the fact that the first redox transition-from phosphate to phosphite-occurs at conditions more reducing than the water$\mathrm{H}_{2}$ reduction potential ( $-0.35 \mathrm{~V}$ for phosphate reduction vs. $0 \mathrm{~V}$ at pH 0 for water to $\mathrm{H}_{2}$ ). A second assumption is that the oxidation of reduced forms of $\mathrm{P}$ such as phosphite proceeds rapidly so that even if phosphite is formed, it will oxidize to phosphate quickly enough that phosphate's chemical behavior effectively describes the bulk geochemistry of phosphorus on the earth's surface. Although the latter assumption has been shown untrue [31, 34] based on oxidation rate experiments of phosphite as salts and in solution [36], the former still presents a conundrum: can reduced oxidation state $\mathrm{P}$ be generated in water-rich environments?

Such a question is especially pertinent to planetary habitability, including the habitability of the early earth. The poor solubility of phosphate could limit the availability of $\mathrm{P}$ on those planets where plate tectonic activity is minimal [37], as the cycling of rock would not renew P sources. Alternatively, planets dominated by ultramafic rocks may not have abundant apatite as a source of $\mathrm{P}$ from weathering, given 
the generally low abundance of $\mathrm{P}$ in ultramafic rocks [38]. Considering the importance of $\mathrm{P}$ in modern biochemical functions from nucleic acids to metabolic pathways [2], this low solubility or abundance could negatively impact the fecundity of a potentially habitable planet. However, if $P$ is reduced from phosphate to phosphite, then the solubility of $\mathrm{P}$ is no longer constrained by poorly soluble phosphate minerals.

For this reason, if there were a route to transforming phosphate to phosphite in a widespread fashion, then the precipitation of phosphate would not deplete total $\mathrm{P}$ concentrations, allowing $\mathrm{P}$ to persist in the aqueous environment as an accessible nutrient. Recently, iron oxidation has been shown to correspond to a concomitant reduction of phosphate to phosphite in iron-rich sediments [34]. Additionally, a role for $P$ redox in biochemistry has been recognized [39], suggesting there might exist a source of reduced $P$ in the environment [40]. We explore here the possibility that electrochemically reducing water-rock interactionsnamely the hydration and oxidation of olivine-result in the production of phosphite, in a way more general than the coupling of $\mathrm{Fe}^{2+}$ to phosphate reduction or through other sources [41]. Given the prevalence of mafic and ultramafic rock in the outer solar system [42], liberation of $P$ as phosphite from reaction of water with ultramafic minerals-even though such rocks are typically very low in total P ( 100 ppm or less, [38]) - may ultimately have been a highly plausible source of $P$ due to the sheer volume of material available to react.

The interactions of water and rock lead to several mineralogical and solutional changes [43]. Rock can act as a buffer to water, moderating its $\mathrm{pH}$ by dissolution and exchange of $\mathrm{H}^{+}$with alkali elements. Rock can also be the cause of significant $\mathrm{pH}$ changes, due to the oxidation of minerals, such as sulfide oxidation leading to low $\mathrm{pH}$, and brucite $\left(\mathrm{Mg}(\mathrm{OH})_{2}\right)$ formation increasing $\mathrm{pH}$. Furthermore, the redox conditions resulting from water-rock reactions includes production of reducing agents such as $\mathrm{H}_{2}$. The rock itself undergoes several changes, including formation of new minerals via hydration, ionic exchange, and dissolution/precipitation; many of these processes result in physical changes to the rock including fracturing induced by volumetric expansion.

The reaction of mafic and ultramafic rocks with water are well known to produce new minerals, predominantly clays, phyllosilicates, and oxides, typically on the timescales of years [44,45]. Clays are the major product of basaltic water-rock reactions whereas oxides and phyllosilicates (primarily serpentine minerals) dominate ultramafic water-rock reactions [46]. The latter process is known as serpentinization and forms serpentinite rocks, and is believed to be widespread in the solar system [4749]). This process also is known to induce an environment that is both alkaline and reducing [50], and has been proposed as a location for the origin of life [51].

\section{Results}

\section{Modeling of Water-Rock Reactions}


Because the redox characteristics of the element phosphorus are typically limited to phosphate and its acid-base chemistry under "typical" aqueous conditions (Figure 1), the effect of water-rock interactions on $P$ are viewed mostly in the context of dissolution of phosphate $[52,53]$. However, it stands to reason that highly exergonic water-rock interactions could potentially promote the more intractable redox transition to phosphite. Alternatively, the speciation of phosphorus within such rocks may begin at a lower redox state than is typically considered (as phosphite exchanging with $\mathrm{SiO}_{4}$ tetrahedra), as the speciation of $\mathrm{P}$ within olivine is unclear (and generally not considered as anything beyond $+5[10,54]$ ). As an example, the serpentinization of olivine couples the transformation of forsterite $\left(\mathrm{Mg}_{2} \mathrm{SiO}_{4}\right)$ to serpentine minerals $\left(\mathrm{Mg}_{3} \mathrm{Si}_{2} \mathrm{O}_{5}(\mathrm{OH})_{4}\right)$, and the oxidation of fayalite $\left(\mathrm{Fe}_{2} \mathrm{SiO}_{4}\right)$ to magnetite $\left(\mathrm{Fe}_{3} \mathrm{O}_{4}\right)$, with the resulting mineralogy dependent on the initial stoichiometry of the olivine.

$(\mathrm{Mg}, \mathrm{Fe})_{2} \mathrm{SiO}_{4}+\mathrm{H}_{2} \mathrm{O}=\mathrm{Mg}_{3} \mathrm{Si}_{2} \mathrm{O}_{5}(\mathrm{OH})_{4}+\mathrm{Fe}_{3} \mathrm{O}_{4}+\mathrm{H}_{2}+\mathrm{SiO}_{2}+\mathrm{Mg}(\mathrm{OH})_{2}$

Brucite is formed when the $\mathrm{Mg} / \mathrm{Fe}$ is greater than 3 , and $\mathrm{SiO}_{2}$ (typically amorphous) is formed when this ratio is less than 3 . The oxidation of iron provides the electrons necessary to reduce neighboring material, whereas the serpentine mineral formation is exothermic, and provides the energy for the batch reaction [55-56]. We investigate the effect of serpentinization on $P$ speciation by two methods: a redox calculation and by batch equilibrium models. First, we constrain the redox-pH conditions of the serpentinization reaction to show that these conditions are conducive to phosphate reduction. Thermodynamic construction of the Eh-pH diagram [57] are at a temperature of $298 \mathrm{~K}\left(25^{\circ} \mathrm{C}\right)$. The reaction of olivine (a solid solution mixture of $\mathrm{Mg}_{2} \mathrm{SiO}_{4}$ and $\mathrm{Fe}_{2} \mathrm{SiO}_{4}$ ) with water to give serpentine, magnetite, and hydrogen $\left(\mathrm{H}_{2}\right.$ to $\mathrm{H}^{+}+\mathrm{e}^{-}$as the half-cell), with $\mathrm{SiO}_{2}$ as quartz or $\mathrm{Mg}(\mathrm{OH})_{2}$ as brucite filling the stoichiometric balance from this reaction.

Notably, this result demonstrates that olivine serpentinization is conducive to phosphite production if the olivine is $50 \%$ forsterite or greater; however, reduction of a few percent of phosphate to phosphite still occurs at higher fayalite content (Figure 1). In general, most olivine is Mg-rich, favoring lower redox conditions.

As noted by Klein et al. [56] the serpentinization of mafic and ultramafic rocks generates $\mathrm{H}_{2}$ only with the oxidation of $\mathrm{Fe}(\mathrm{II})$-bearing minerals, and some of these minerals form solid solutions with serpentinization products, as ferrobrucite, $\mathrm{Fe}(\mathrm{OH})_{2}$, does with brucite, and greenalite, $\mathrm{Fe}_{3} \mathrm{Si}_{2} \mathrm{O}_{5}(\mathrm{OH})_{4}$, does with Mg-serpentine minerals. To this end, olivine serpentinization was modeled using HSC Chemistry for batch equilibria at higher temperature and with more consideration for solid solutions, along with changing water/rock ratios, coupled to an investigation of P speciation. These models employed the equilibrium chemistry calculator as part of HSC Chemistry (version 7.1, Outokompu Research Oy)[1]. In these models, either the water to rock ratio was set to 1:1 (by mass) and temperature slowly increased, or the temperature was set to $250^{\circ} \mathrm{C}$ and the water to rock ratio increased (from $\sim 0$ to 0.25 ). The rock composition was set to be initially equivalent to $70 \%$ forsterite and $30 \%$ fayalite. We specifically modeled a dunite rock, where olivine is the sole silicate present, though similar test models with pyroxene present 
did not substantially change the results with respect to phosphorus. The water reacting with the rock was set to a pH of 7.5, with $0.5 \mathrm{M} \mathrm{NaCl}$, and low redox state (in equilibrium with an $\mathrm{N}_{2}$ atmosphere). The system was held at a constant 500 bar pressure (50 MPa). We added data for ferrobrucite, greenalite, and minnesotaite [58], and the remainder of the data came from the existing HSC database. Solid solutions were assumed between olivine, serpentine minerals, talc minerals, and brucite. Due to a lack of thermodynamic data for reduced $\mathrm{P}$ compounds, and for $\mathrm{P}$ dissolved in olivine/glass, phosphorus was considered to be present in the rock as $\mathrm{P}_{2} \mathrm{O}_{5}$ at $1000 \mathrm{ppm}$ of the total rock weight. Aqueous speciation was constrained using the Debye-Huckel approximation of activity coefficients. The pH was "fixed" with a buffer consisting of $\mathrm{Na}_{2} \mathrm{~S} / \mathrm{H}_{2} \mathrm{~S}$ in a 1:4 ratio $(0.1 \mathrm{M}$ total $\mathrm{Na}$ added) that kept $\mathrm{pH}$ near 7.5. The species investigated in this model are provided in the methods below.

These batch equilibria models of an olivine dunite undergoing serpentinization reactions reveal that reduction of phosphate occurs readily at incipient serpentinization (i.e., at low water-rock ratios) (Figure 2). This is because water is potentially an oxidant for phosphite, and based on thermodynamic equilibria will ultimately oxidize phosphite to phosphate (though in practice it does not readily oxidize in water on timescales of greater than 5 years [34]. Reduced oxidation state $P$ persists at about $0.3 \%$ of the total $P$ even after the incipient serpentinization has completed (Figure 2b). These models, based off prior serpentinization batch equilibria models [58], demonstrate that reducing conditions pervade ultramafic rocks when the first interactions with water occur [59].

\section{Phosphorus Reactions and Speciation}

The above models demonstrate that the reduction of phosphate to phosphite is plausible within serpentinizing rock. This reduction occurs with the concomitant oxidation of iron, and is similar to prior work demonstrating iron oxidation coupled to phosphate reduction [34]. However, in contrast to the low production (1-4\%) of phosphite reported by $\mathrm{Fe}^{2+} \otimes \mathrm{Fe}^{3+}$, these thermodynamic models predict the highly exergonic nature of serpentinization may be able to better power this reduction reaction than the amount produced by this diagenetic process, especially at low water to rock ratios.

We contrast these model results to P speciation within serpentinites. Serpentinites were collected from

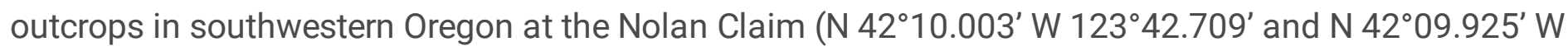
$\left.123^{\circ} 42.719^{\prime}\right)$ in Josephine County, OR, USA. These rocks are part of the Josephine Ophiolite in the Klamath Mountains [60,61], and were a sequence of ultramafic rocks (dunite and harzburgite) with a formation age of 157 million years. Fresh samples were taken along the Josephine creek, then powdered and analyzed by Raman, XRD, and XRF. Both Raman and XRD show that the main mineralogy of these samples is the serpentine mineral antigorite (see $\mathrm{SI}$ ). The composition of these rocks determined by XRF (see $\mathrm{SI}$ ) shows they are composed primarily of magnetite and serpentine minerals, and that they are depleted in $\mathrm{P}$ and enriched in $\mathrm{Cr}$ and $\mathrm{Ni}$ (consistent with their ultramafic origin).

Phosphorus compounds were extracted from these serpentinites (see methods) and analyzed by ${ }^{31} \mathrm{P}$ NMR spectroscopy (Figure 3). This spectrum shows a peak occurring within the region of phosphite that 
splits (doublet at 4.9 and $1.4 \mathrm{ppm}$ ) when the coupling to hydrogen is permitted with a $\mathrm{J}_{\mathrm{P}-\mathrm{H}}$ coupling constant of $565 \mathrm{~Hz}$. This coupling constant is diagnostic of phosphite [29], indicating phosphite is present within the serpentinite and is the major $\mathrm{P}$ species, formed during the highly reducing alteration of olivine. The other associated peaks correspond to phosphate $(5.6 \mathrm{ppm})$ and pyrophosphate $(-4.6 \mathrm{ppm})$. The presence of both phosphate and pyrophosphate may be due to a few causes. For one, the presence of phosphate may suggest incomplete reduction of phosphate to phosphite. Then, when the rock is serpentinizing, the exergonic/exothermic reaction results in the dimerization of phosphate. Alternatively, and perhaps more likely, the presence of pyrophosphate and phosphate may suggest that phosphite has been oxidized by free radicals such as $\mathrm{OH}$ [62], possibly formed by reaction of $\mathrm{O}_{2}$ with native metals present in the serpentinite [63], which may produce $\mathrm{H}_{2} \mathrm{O}_{2}$ that could then react to produce $\mathrm{OH}$ [64].

Modeling results and analysis of natural samples both demonstrate that $\mathrm{P}$ in ultramafic rocks that serpentinize is present in reduced form as phosphite. These results highlight a new role for serpentinization in planetary habitability. In addition to heat generation and low redox conditions [65], serpentinization also affects $\mathrm{P}$ speciation. Due to the higher solubility of phosphite relative to phosphate $[66,67]$, the serpentinization process may liberate $P$ into water as rocks serpentinize. Notably, the serpentinized rock is significantly lower in total P content than associated unaltered rocks $([68,69]$, Table S1). This may imply that as water reacts with the serpentinite that further extraction occurs due to the higher solubility of phosphite. As an illustration of this process, the addition of divalent cations (in this case, $\mathrm{Ca}^{2+}$ ) to a solution of both phosphate and phosphite results in the precipitation of phosphate but leaves phosphite relatively unaffected (Figure 4). This implies that the phosphite is more soluble, and more easily extracted from the serpentinizing rock than is phosphate.

\section{Discussion}

Nutrient availability is a key factor in what makes a world habitable. If $\mathrm{P}$ is an important constituent of biochemical processes beyond the earth, then understanding its liberation from rock provides constraints on habitability. We propose here that $P$ in ultramafic rocks is liberated first by the transformation of phosphate to phosphite (or phosphite is intrinsic to olivine) through a coupled oxidation with iron, then the flushing of phosphite from the rock as water continues to react with it. To this end, this otherwise intractable element may become bioavailable for incipient life developing on other worlds, such as icy moons $[27,65]$, or on a primitive, ultramafic earth.

The results presented here are specific to serpentinizing rock (and specifically, to three samples of serpentinite separated by a few tens of meters), which is necessarily ultramafic. Moreover, it is also not known if this process is common to serpentinites as only one rock outcrop was investigated (though these serpentinites are not especially unique). Mafic rocks, such as basalts, may not experience similar changes to $P$ speciation [46], as serpentinization is halted in these rocks by the production of ferrous clays, preventing the development of a redox driver for phosphate reduction. However, if oxidation of iron occurs as basalts alter under reduced conditions, then it may still be feasible that phosphate is reduced to 
phosphite. As of yet, phosphite has not been reported as a species in basalt, through few analyses have been performed with proton coupling that could reveal P-H interactions [70-72].

Furthermore, these results do clearly show that phosphorus and phosphate are not synonymous in geologic systems, and great care should be taken in assuming that measured phosphorus (for instance, by ICP) is in fact phosphate and not the more soluble phosphite ion. The general assumption of $P$ as phosphate needs closer inspection for those systems where redox may have occurred, especially the iron(II) to (III) transition, under otherwise anaerobic conditions.

The speciation of phosphorus within olivine is typically considered to be phosphate, with a substitution for a $\mathrm{SiO}_{4}$ tetrahedron coupled to a vacancy or substitution by an alkali metal for the divalent metal position (to balance charge). The redox conditions of iron in olivine may be such that phosphorus is present instead in reduced form (for instance, $\mathrm{Fe}^{2+}+\mathrm{Si}^{4+}$ are substituted instead by $\mathrm{Fe}^{3+}$ and $\mathrm{P}^{3+}$ ). Some olivine measurements have shown increases in $\mathrm{Al}^{3+}$ and $\mathrm{Cr}^{3+}$ with increasing $\mathrm{P}$ [10]. If such a conjecture is shown plausible, then $\mathrm{P}$ in olivine may intrinsically be present as phosphite in some cases.

Given that olivine is the dominant mineral of the upper mantle, and that the upper mantle makes up about $10 \%$ of the earth's total mass, $P$ in olivine should have been a volumetrically significant source for the early earth, prior to the development of abundant crust. Additionally, the rocky material at the water-rock interface of several icy moons is likely composed of ultramafic rock. As such, the proposed redox reaction that then allows for the liberation of phosphorus may have been widely important for potentially habitable worlds. The liberation of this phosphite may have provided an abundance of phosphorus for developing life, whereupon the oxidation of phosphite could have provided energy [73] leading to organophosphates, and ultimately to nucleic acid-based biochemistry.

\section{Methods}

Species considered in the batch equilibria models include the gases $\mathrm{N}_{2}, \mathrm{H}_{2}$; an aqueous solution consisting of $\mathrm{H}_{2} \mathrm{O}, \mathrm{Ca}^{2+}, \mathrm{CaOH}^{+}, \mathrm{H}_{2} \mathrm{~S}, \mathrm{HS}^{-}, \mathrm{Fe}^{3+}, \mathrm{Fe}^{2+}, \mathrm{FeO}^{+}, \mathrm{FeO}_{2}{ }^{-}, \mathrm{FeOH}^{2+}, \mathrm{FeOH}^{+}, \mathrm{Fe}(\mathrm{OH})_{2}{ }^{+}, \mathrm{Fe}(\mathrm{OH})_{3}{ }^{-}$, $\mathrm{Fe}(\mathrm{OH})_{4}{ }^{-}, \mathrm{H}^{+}, \mathrm{H}_{2}, \mathrm{HFeO}_{2}{ }^{-}, \mathrm{HO}_{2}{ }^{-}, \mathrm{HPO}_{3}{ }^{2-}, \mathrm{HPO}_{4}{ }^{2-}, \mathrm{H}_{2} \mathrm{PO}_{2}{ }^{-}, \mathrm{H}_{2} \mathrm{PO}_{3}{ }^{-}, \mathrm{H}_{2} \mathrm{PO}_{4}{ }^{-}, \mathrm{HSiO}_{3}{ }^{-}, \mathrm{H}_{2} \mathrm{SiO}_{4}{ }^{2-}, \mathrm{H}_{3} \mathrm{SiO}_{4}{ }^{-}, \mathrm{Cl}^{-}$, $\mathrm{Mg}^{2+}, \mathrm{MgOH}^{+}, \mathrm{Na}^{+}, \mathrm{OH}^{-}, \mathrm{PO}_{4}{ }^{3-}, \mathrm{SiO}_{4}{ }^{4-}$; Diopside as $\mathrm{CaMgSi}_{2} \mathrm{O}_{6}$; wustite as $\mathrm{FeO}$; hematite as $\mathrm{Fe}_{2} \mathrm{O}_{3}$; magnetite as $\mathrm{Fe}_{3} \mathrm{O}_{4}$; a brucite solid solution as $\mathrm{Fe}(\mathrm{OH})_{2}$, and $\mathrm{Mg}(\mathrm{OH})_{2}$; an olivine solid solution as $\mathrm{Fe}_{2} \mathrm{SiO}_{4}$ and $\mathrm{Mg}_{2} \mathrm{SiO}_{4}$; a pyroxene solid solution as $\mathrm{FeSiO}_{3}$ and $\mathrm{MgSiO}_{3}$; a greenalite-serpentine solid solution as $\mathrm{Fe}_{3} \mathrm{Si}_{2} \mathrm{O}_{5}(\mathrm{OH})_{4}$ and $\mathrm{Mg}_{3} \mathrm{Si}_{2} \mathrm{O}_{5}(\mathrm{OH})_{4}$; a minnesotaite-talc solid solution as $\mathrm{Fe}_{3} \mathrm{Si}_{4} \mathrm{O}_{10}(\mathrm{OH})_{2}$, and $\mathrm{Mg}_{3} \mathrm{Si}_{4} \mathrm{O}_{10}(\mathrm{OH})_{2}$; a sulfide $\mathrm{pH}$ buffer introduced as the salt $\mathrm{Na}_{2} \mathrm{~S}$ with $\mathrm{H}_{2} \mathrm{~S}(\mathrm{aq})$ in a 1:4 ratio (pH 7.5); quartz as $\mathrm{SiO}_{2}$; phosphorus as solid $\mathrm{P}_{2} \mathrm{O}_{5}$ and $\mathrm{P}_{2} \mathrm{O}_{3}$; and salt as $\mathrm{NaCl}$.

Laser Raman spectroscopy was utilized to determine the mineral identity. An Enwave $\mu$ Sense Raman microscope operating at $785 \mathrm{~nm}$ (Model No. EZI-785-A2) was used. The Raman microscope was a Leica DM300 microscope equipped with three objective lenses $(\times 4 / 0.1$ NA. $\times 10 / 0.25$ NA and $\times 40 / 0.65$ NA). 
Integration time is $30 \mathrm{~s}$ to $60 \mathrm{~s}$. Crystal Sleuth software was utilized to determine mineral identity. Database searching compared the sample with the RRUFF database [74].

Powder XRD was performed using an Olympus BTX Benchtop XRD (with a Cu cathode) to verify mineral identity further. A calibrated ion chamber, Ludium Model 9 - 3 Radiation Ion Chamber, was obtained for the measurements which measured radiation level counting range of 0 to $2000 \mathrm{uSv} / \mathrm{Hr}$. Crystal Sleuth software was utilized to determine the mineral identity. Database searching compared the sample with the RRUFF database [74].

Samples of the serpentinite rock were analyzed by X-Ray Fluorescence (XRF) following prior methods [75], at Hamilton College (NY) on a Bruker AXS S8 Tiger Wavelength Dispersive X-Ray Fluorescence (WDXRF).

Serpentinites were collected from southwestern Oregon as part of the Josephine Ophiolite in the Klamath Mountains [69]. Powdered samples were extracted using $15 \mathrm{~mL}$ of a 1:4 EDTA NaOH solution, then concentrated, rehydrated with $\mathrm{D}_{2} \mathrm{O}$, and analyzed on a Bruker Neo 600 NMR for 11500 scans in both $\mathrm{H}$ coupled and decoupled modes.

A solution of $\mathrm{Na}_{2} \mathrm{HPO}_{3}(0.05 \mathrm{M})$ was prepared by reacting $\mathrm{NaOH}$ and $\mathrm{H}_{3} \mathrm{PO}_{3}$ in solution, to which $\mathrm{Na}_{2} \mathrm{HPO}_{4}$ was added to reach a $0.05 \mathrm{M}$ solution of phosphate, giving a 1:1 phosphite to phosphate mixture consisting of $0.05 \mathrm{M}$ of both species. The solution was poured into several vials. To these vials, a solution of $0.1 \mathrm{M} \mathrm{CaCl}_{2}$ (prepared by mixing anhydrous $\mathrm{CaCl}_{2}$ in de-ionized water) was added in varying total $\mathrm{Ca} / \mathrm{P}$ ratios. An $0.8 \mathrm{~mL}$ aliquot of the solution within each vial was removed, filtered, and mixed with $0.2 \mathrm{~mL}$ of $\mathrm{D}_{2} \mathrm{O}$, and analyzed by ${ }^{31} \mathrm{P}$ NMR, as per Sect. 1.5. 1024 scans were taken for each of these samples.

\section{Declarations}

\section{Acknowledgements.}

This work was jointly supported by NSF and the NASA Astrobiology Program, under the NSF Center for Chemical Evolution, CHE-1504217, and by the NASA Exobiology program (80NSSCC18K1288).

\section{References}

1. D. M. Karl, Microbially mediated transformations of phosphorus in the sea: new views of an old cycle. Ann. Rev. Marine Sci. 6, 279-337 (2014).

2. F. H. Westheimer, Why nature chose phosphates. Science 235, 1173-1178 (1987).

3. G. M. Filippelli, The global phosphorus cycle: past, present, and future. Elements 4, 89-95 (2008).

4. J. K. Lassila, J. G. Zalatan, D. Herschlag, Biological phosphoryl-transfer reactions: understanding mechanism and catalysis. Ann. Rev. Biochem. 80, 669-702 (2011). 
5. J. Elser, E. Bennett, E. Phosphorus cycle: a broken biogeochemical cycle. Nature 478, 29-31 (2011).

6. J. E. Goldford, H. Hartman, T. F. Smith, D. Segrè, Remnants of an ancient metabolism without phosphate. Cell 168, 1126-1134 (2017)..

7. F. Wolfe-Simon et al., A bacterium that can grow by using arsenic instead of phosphorus. Science 332, 1163-1166 (2011).

8. M. A. Pasek, J. M. Sampson, Z. Atlas, Redox chemistry in the phosphorus biogeochemical cycle. Proc. Natl. Acad. Sci. USA 111, 15468-15473 (2014).

9. W. Bains, J. J. Petkowski, C. Sousa-Silva, S. Seager, New environmental model for thermodynamic ecology of biological phosphine production. Sci. Tot. Env. 658, 521-536 (2019).

10. M. S. Milman-Barris et al., Zoning of phosphorus in igneous olivine. Contr. Min. Pet. 155, 739-765 (2008).

11. F. Brunet, G. Chazot, Partitioning of phosphorus between olivine, clinopyroxene and silicate glass in a spinel Iherzolite xenolith from Yemen. Chem. Geo. 176, 51-72 (2001).

12. E. B. Watson, D. J. Cherniak, M. E. Holycross, Diffusion of phosphorus in olivine and molten basalt. Am. Min. 100, 2053-2065 (2015).

13. S. O. Agrell, N. R. Charnley, G. A. Chinner, Phosphoran olivine from Pine Canyon, Piute Co., Utah. Min. Mag. 62, 265-269 (1998).

14. C-M. Xing, C. Y. Wang, W. Tan. Disequilibrium growth of olivine in mafic magmas revealed by phosphorus zoning patterns of olivine from mafic-ultramafic intrusions. Earth Planet. Sci. Lett. 479, 108-119 (2017).

15. I. Baziotis al., Phosphorus zoning as a recorder of crystal growth kinetics: application to secondgeneration olivine in mantle xenoliths from the Cima Volcanic Field. Contr. Min. Pet. 172, 58 (2017).

16. J. D. Toner, D. C. Catling, A carbonate-rich lake solution to the phosphate problem of the origin of life. Proc. Natl. Acad. Sci. USA 117, 883-888 (2019).

17. B. Burcar et al., Darwin's warm little pond: a one-pot reaction for prebiotic phosphorylation and the mobilization of phosphate from minerals in a urea-based solvent. Angew. Chem. Int. Ed. 55, 1324913253 (2016).

18. B. Burcar et al., A stark contrast to modern Earth: phosphate mineral transformation and nucleoside phosphorylation in an iron- and cyanide-rich early Earth scenario. Angew. Chem. Int. Ed. 58, 1698116987 (2019).

19. N. V. Sobolev et al., Olivine inclusions in Siberian diamonds: high-precision approach to minor elements. Eur. J. Min. 20, 305-315 (2008).

20. J. C. De Hoog, L. Gall, D. H. Cornell, Trace-element geochemistry of mantle olivine and application to mantle petrogenesis and geothermobarometry. Chem. Geo. 270, 196-215 (2010).

21. C. Herzberg, K. Condie, J. Korenaga, Thermal history of the Earth and its petrological expression. Earth Planet. Sci. Lett. 292, 79-88 (2010). 
22. E. G. Nisbet, M. J. Cheadle, N. T. Arndt, M. J. Bickle, Constraining the potential temperature of the Archaean mantle: A review of the evidence from komatiites. Lithos, 30, 291-307 (1993).

23. S. A. Wilde, J. W. Valley, W. H. Peck, C. M. Graham, Evidence from detrital zircons for the existence of continental crust and oceans on the Earth 4.4 Gyr ago. Nature 409, 175-178 (2001).

24. C. T. Adcock, E. M. Hausrath, P. M. Forster, Readily available phosphate from minerals in early aqueous environments on Mars. Nat. Geosci. 6, 824-827 (2013).

25. O. L. Kuskov, V. A. Kronrod, Core sizes and internal structure of Earth's and Jupiter's satellites. Icarus 151, 204-227 (2001).

26. O. L. Kuskov, V. A. Kronrod. "Internal structure of Europa and Callisto. Icarus 177 550-569 (2005).

27. C. R. Glein, J. A. Baross, J. H. Waite Jr, The pH of Enceladus' ocean. Geochim. Cosmochim. Ac. 162, 202-219 (2015).

28. M. A. Pasek, D. S. Lauretta, Aqueous corrosion of phosphide minerals from iron meteorites: a highly reactive source of prebiotic phosphorus on the surface of the early Earth. Astrobiology 5, 515-535 (2005).

29. M. A. Pasek, J. P. Dworkin, D. S. Lauretta, A radical pathway for organic phosphorylation during schreibersite corrosion with implications for the origin of life. Geochim. Cosmochim. Ac. 71, 17211736 (2007).

30. M. A. Pasek, Rethinking early Earth phosphorus geochemistry. Proc. Natl. Acad. Sci. USA 105, 853858 (2008).

31. M. A. Pasek, J. P. Harnmeijer, R. Buick, M. Gull, Z. Atlas, Evidence for reactive reduced phosphorus species in the early Archean ocean. Proc. Natl. Acad. Sci. USA, 110, 10089-10094 (2013).

32. M. Gull et al., Nucleoside phosphorylation by the mineral schreibersite. Sci. Rep. 5, 17198 (2015).

33. D. J. Ritson, S. J. Mojzsis, J. D. Sutherland, Supply of phosphate to early Earth by photogeochemistry after meteoritic weathering. Nat. Geosci. 13, 344-348 (2020).

34. B. Herschy et al., Archean phosphorus liberation induced by iron redox geochemistry. Nat. Comm. 9 , 1346 (2018).

35. M. A. Pasek, Phosphorus volatility in the early solar nebula. Icarus 317, 59-65 (2019).

36. C. Gibard et al., Geochemical sources and availability of amidophosphates on the early Earth. Angew. Chem. Int. Ed. 58, 8151-8155 (2019).

37. P. J. Cook, M. W. McElhinny. A reevaluation of the spatial and temporal distribution of sedimentary phosphate deposits in the light of plate tectonics. Econ. Geo. 74, 315-330 (1979).

38. S. Porder, S. Ramachandran, The phosphorus concentration of common rocks-a potential driver of ecosystem P status. Plant Soil 367, 41-55 (2013).

39. B. Schink, M. Friedrich, Phosphite oxidation by sulphate reduction. Nature 406, 37-37 (2000).

40. A. K. White, W. W. Metcalf, Microbial metabolism of reduced phosphorus compounds. Annu. Rev. Microbiol. 61, 379-400 (2007). 
41. M. Pasek, A role for phosphorus redox in emerging and modern biochemistry. Curr. Op. Chem. Bio 49, 53-58 (2019).

42. T. J. McCoy et al., Formation of vesicles in asteroidal basaltic meteorites. Earth Planet. Sci. Lett. 246, 102-108 (2006).

43. S. L. Brantley, J. D. Kubicki, A. F. White (Eds.), Kinetics of water-rock interaction (Springer, 2008), 833 pp.

44. T. M. McCollom et al., Temperature trends for reaction rates, hydrogen generation, and partitioning of iron during experimental serpentinization of olivine. Geochim. Cosmochim. Ac. 181, 175-200 (2016).

45. H. M. Lamadrid et al., Effect of water activity on rates of serpentinization of olivine. Nature Comm. $\mathbf{8}$, 1-9 (2017).

46. K. L. Smith, A. R. Milnes, R. A. Eggleton, Weathering of basalt: formation of iddingsite. Clays Clay Min. 35, 418-428 (1987).

47. K. Tomeoka, P. R. Buseck, Matrix mineralogy of the Orgueil Cl carbonaceous chondrite. Geochim. Cosmochim. Ac. 52, 1627-1640 (1988).

48. M. Y. Zolotov, E. L. Shock, Energy for biologic sulfate reduction in a hydrothermally formed ocean on Europa. J. Geophys. Res. Planets 108, E001966 (2003).

49. Y. Sekine et al. High-temperature water-rock interactions and hydrothermal environments in the chondrite-like core of Enceladus. Nat. Comm. 6, 1-8 (2015).

50. J. B. Moody, Serpentinization: a review. Lithos 9, 125-138 (1976).

51. M. J. Russell, A. J. Hall, W. Martin, Serpentinization as a source of energy at the origin of life. Geobio. 8, 355-371 (2010).

52. R. E. Hannigan, E. R. Sholkovitz, The development of middle rare earth element enrichments in freshwaters: weathering of phosphate minerals. Chem. Geo. 175, 495-508 (2001).

53. R. Flicoteaux, J. Lucas, "Weathering of phosphate minerals" in Phosphate Minerals J. O. Nriagu, P. B. Moore, Eds. (Springer 1984) pp. 292-317.

54. G. Mallmann, H. St C. O'Neill, S. Klemme. Heterogeneous distribution of phosphorus in olivine from otherwise well-equilibrated spinel peridotite xenoliths and its implications for the mantle geochemistry of lithium. Contr. Min. Pet. 158, 485-504 (2009).

55. C. Oze, M. Sharma, Serpentinization and the inorganic synthesis of $\mathrm{H}_{2}$ in planetary surfaces. Icarus 186, 557-561 (2007)..

56. F. Klein, W. Bach, T. M. McCollom, Compositional controls on hydrogen generation during serpentinization of ultramafic rocks. Lithos 178, 55-69 (2013).

57. G. Faure, Principles and applications of geochemistry. (Prentice Hall 1997) 600 pp.

58. T. M. McCollom, W. Bach, Thermodynamic constraints on hydrogen generation during serpentinization of ultramafic rocks. Geochim. Cosmochim. Ac. 73, 856-875 (2009).

59. W. Bach et al. Unraveling the sequence of serpentinization reactions: petrography, mineral chemistry, and petrophysics of serpentinites from MAR 15 N (ODP Leg 209, Site 1274). Geophys. Res. Lett. 33, 
L13306 (2006).

60. G. D. Harper, The Josephine ophiolite, northwestern California. Geo. Soc. Am. Bull. 95, 1009-1026 (1984).

61. Y. Sonzogni, A. H. Treiman, S. P. Schwenzer, Serpentinite with and without brucite: A reaction pathway analysis of a natural serpentinite in the Josephine ophiolite, California. J. Min. Petrol. Sci. 112, 5976 (2017).

62. M. A. Pasek et al., Production of potentially prebiotic condensed phosphates by phosphorus redox chemistry. Angew. Chem. Int. Ed. 47, 7918-7920 (2008).

63. H. J. B. Dick, Terrestrial nickel-iron from the Josephine Peridotite, its geologic occurrence, associations, and origin." Earth Planet. Sci. Lett. 24, 291-298 (1974).

64. J. A. Bergendahl, T. P. Thies. Fenton's oxidation of MTBE with zero-valent iron. Water Res. 38, 327334 (2004).

65. M. J. Russell et al., The drive to life on wet and icy worlds. Astrobiology 14, 308-343 (2014).

66. A. Gulick, Phosphorus as a factor in the origin of life. Am. Sci. 43, 479-489 (1955).

67. M. A. Pasek, M. Gull, B, Herschy, Phosphorylation on the early earth. Chem. Geo. 475, 149-170 (2017).

68. J. Malpas, "Serpentine and the geology of serpentinized rocks" in The Ecology of Areas with Serpentinized Rocks (Springer 1992), pp. 7-30.

69. G. D. Harper, J. B. Saleeby, M. Heizler, Formation and emplacement of the Josephine ophiolite and the Nevadan orogeny in the Klamath Mountains, California-Oregon: U/Pb zircon and ${ }^{40} \mathrm{Ar} /{ }^{39} \mathrm{Ar}$ geochronology. J. Geophys. Res. Solid Earth 99, 4293-4321 (1994).

70. R. W. McDowell, B. Cade-Menun, I. Stewart, Organic phosphorus speciation and pedogenesis: analysis by solution ${ }^{31} \mathrm{P}$ nuclear magnetic resonance spectroscopy. Eur. J. Soil Sci. 58, 1348-1357 (2007).

71. P. N. C. Murphy, A. Bell, B. L. Turner, Phosphorus speciation in temperate basaltic grassland soils by solution ${ }^{31}$ P NMR spectroscopy. Eur. J. Soil Sci. 60, 638-651 (2009).

72. B. Mysen, Phosphorus speciation changes across the glass transition in highly polymerized alkali silicate glasses and melts. Am. Min. 81, 1531-1534 (1996).

73. M. A. Pasek Thermodynamics of Prebiotic Phosphorylation. Chem. Rev. in press (2020).

74. T. Laetsch, R. T. Downs, "Software for identification and refinement of cell parameters from powder diffraction data of minerals using the RRUFF Project and American Mineralogist Crystal Structure Databases" in Abstracts of the 19th General Meeting of the International Mineralogical Association (IMA 2006).

75. T. Feng, C. Lang, M. A. Pasek, The origin of blue coloration in a fulgurite from Marquette, Michigan. Lithos, 342, 288-294 (2019).

\section{Figures}




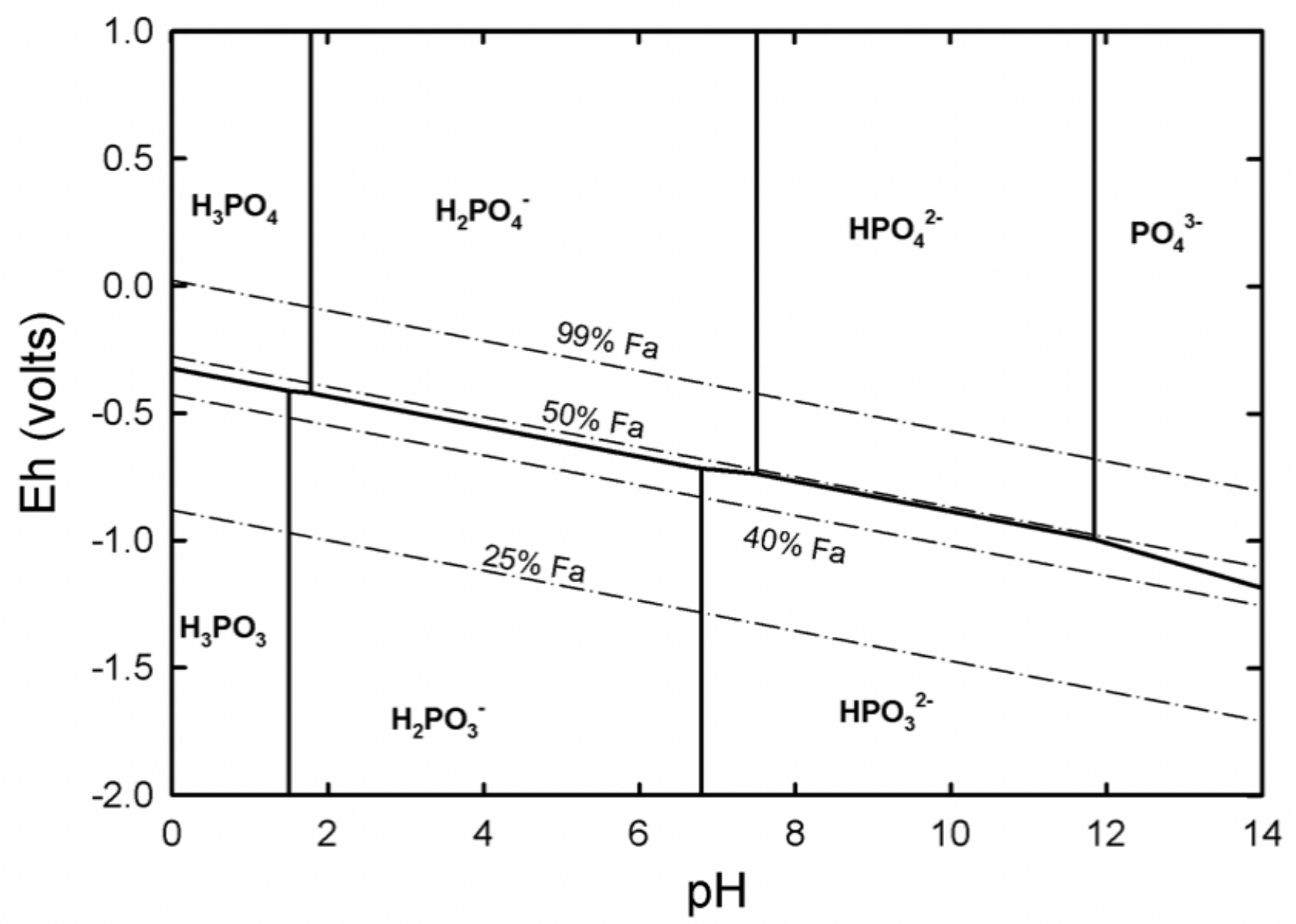

Figure 1

Eh-pH diagram ( $1 \mathrm{~atm}, 25^{\circ} \mathrm{C}$ ) for phosphorus (solid lines), with dashed lines showing redox conditions associated with serpentinization of olivine ranging from $99 \%$ fayalite to $25 \%$ fayalite. Note that solid, nonvertical Eh-pH lines specifically illustrate where the activity of phosphite equals the activity of phosphate $(1: 1)$, and that these lines are elevated by about $0.12 \mathrm{~V}$ for a 1:100 ratio. 

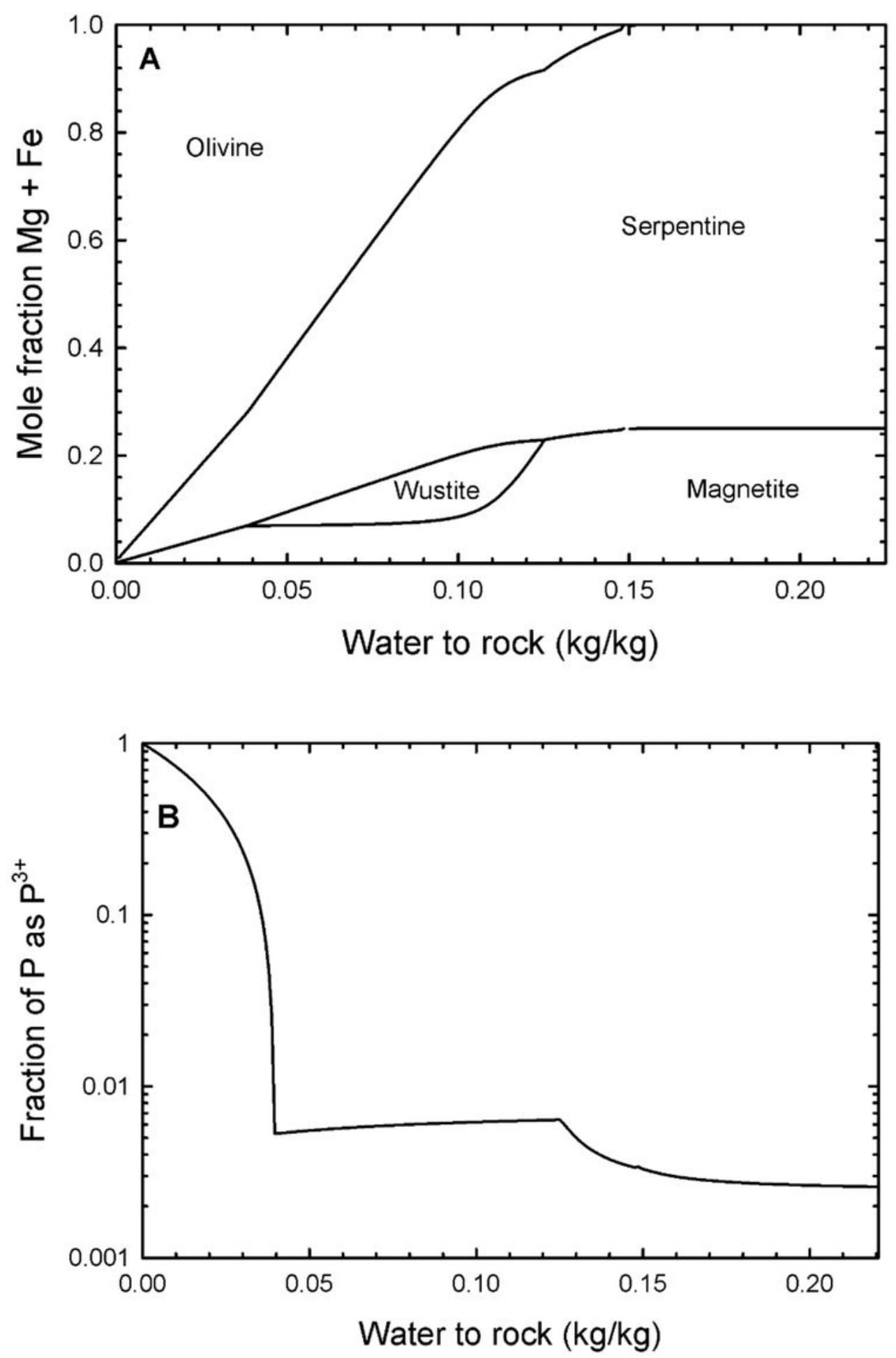

Figure 2

Batch equilibria models of serpentinizing rock, following methods presented by Klein [56]. A) With increasing water content, the olivine hydrates to serpentine with iron oxidizing to wüstite, then to magnetite at these temperatures (in agreement with data from [56], see SI). B) The P speciation is initially almost all reduced at low water-rock ratios, then slowly oxidizes but maintains $0.2-0.3 \%$ phosphite as a fraction of all P. 


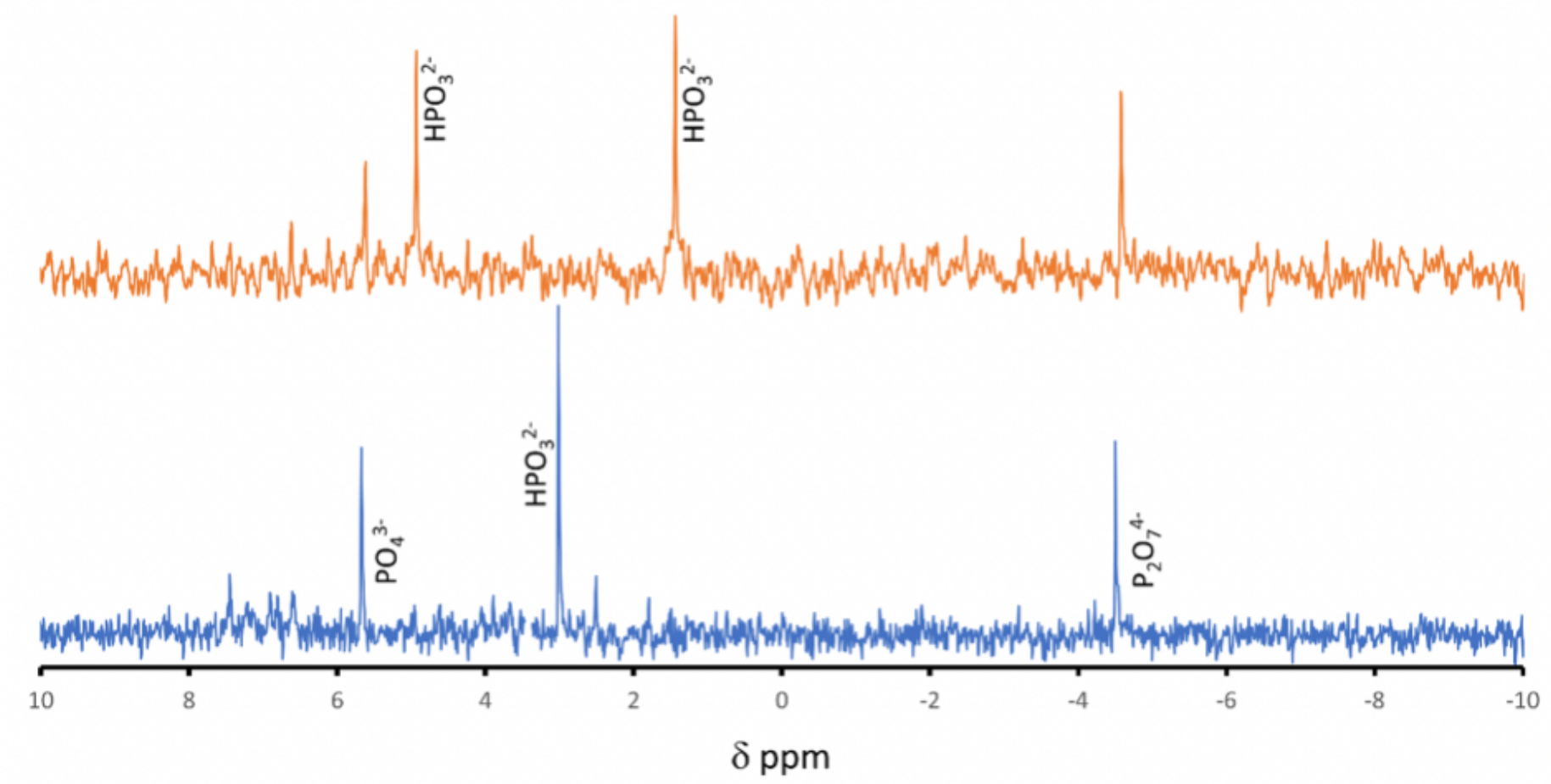

Figure 3

31P NMR spectrum of phosphorus extracted from a serpentinite from Josephine county, OR, USA (pH 13). The $\mathrm{x}$-axis is in ppm, which is a frequency spectrum normalized to 0 for $85 \% \mathrm{H} 3 \mathrm{PO} 4$. The singlet at $3 \mathrm{ppm}$ (bottom, proton-decoupled) splits into a wide doublet (top, proton-coupled) with a J-coupling constant of $565 \mathrm{~Hz}$ and is characteristic of the ion phosphite. The concentration of $\mathrm{P}$ measured using this method was about 10-4 $\mathrm{M}$ with respect to this signal to noise ratio for these scans [29], corresponding to an extraction of about $90 \%$ of the total P. The peak at $5.6 \mathrm{ppm}$ is orthophosphate, and at $-4.5 \mathrm{ppm}$ is pyrophosphate. 


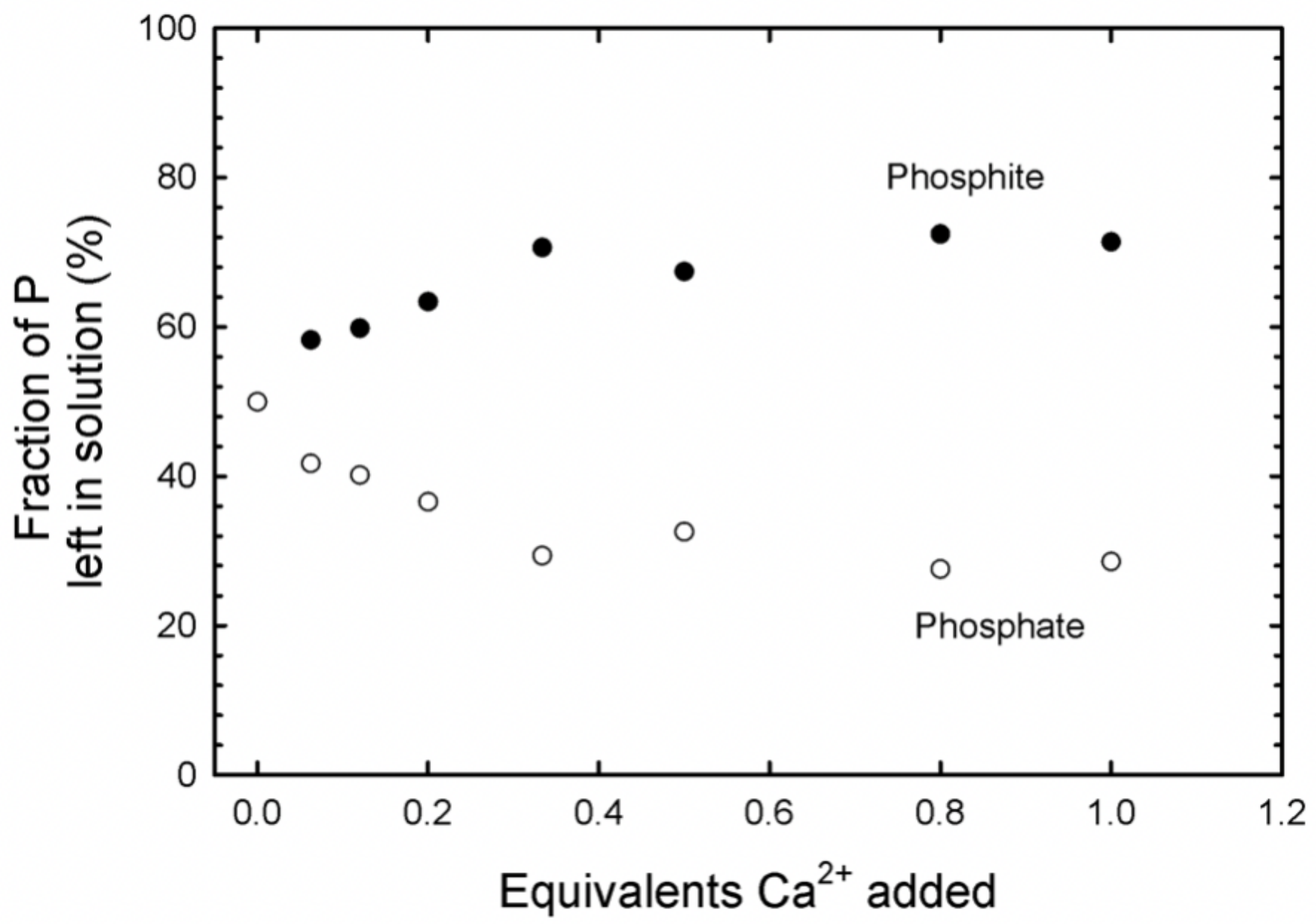

Figure 4

The fraction of initially equimolar $(0.05 \mathrm{M})$ phosphite and phosphate $\left(\mathrm{pH}\right.$ of $\left.8,25^{\circ} \mathrm{C}\right)$ upon the sequential addition of a total of one equivalent (based on $\mathrm{Ca} / \mathrm{Ptot}$ ) of $\mathrm{CaCl} 2$ measured by 31P NMR. With increasing $\mathrm{Ca} 2+$, phosphite remains preferentially in solution. Phosphite and phosphate were dissolved as their sodium salts, Na2HPO3 and Na2HPO4.

\section{Supplementary Files}

This is a list of supplementary files associated with this preprint. Click to download.

- Supplementallnformation.pdf 